\title{
Effects of heavy metals and pesticides on survival of Artemia franciscana
}

\author{
Marcel Falis, Michaela Špalková, Jaroslav Legáth \\ University of Veterinary Medicine and Pharmacy in Košice, Department of Pharmacology and Toxicology, \\ Košice, Slovak Republic
}

Received July 8, 2013

Accepted January 23, 2014

\begin{abstract}
Assessment of the potential risk of pesticides is an important part of registration procedures in many countries. However, risk assessment of several pesticides used during the growing season has not been carried out. The aim of this study was to investigate the effects of pesticides (azoxystrobin and glyphosate), heavy metals (cadmium chloride, potassium dichromate, zinc disulphate) and their combinations on lethality to Artemia franciscana. In total, 1,250 freshly hatched nauplii of $A$. franciscana were used in the study. They were placed in 125 Petri dishes (10 nauplii in one Petri dish) containing $10 \mathrm{ml}$ of azoxystrobin, glyphosate, cadmium chloride, potassium dichromate and zinc sulphate separately, or their combinations; the control dish contained only sea water. Each experimental set consisted of 50 nauplii which were divided into five replicates of 10 nauplii per replicate. Live $A$. franciscana were counted after 24,48 , 72 and $96 \mathrm{~h}$ and the numbers were compared with the control group. A significant $(P<0.05)$ decrease in lethality was observed after exposure to azoxystrobin in combination with glyphosate after 48, 72 and $96 \mathrm{~h}$ of exposure, in combination with glyphosate and potassium dichromate after $48 \mathrm{~h}$ of exposure, and in combination with glyphosate and zinc disulphate after 48, 72 and $96 \mathrm{~h}$ of exposure. The results of this study provide information about the combined toxicity of pesticides used during the growing season and some heavy metals as major pollutants of the rural environment. A study of this kind has not been conducted yet. Further research for investigation of the combined toxicity of pollutants and pesticides is required.
\end{abstract}

Azoxystrobin, glyphosate, cadmium chloride, potassium dichromate, zinc disulphate

Intensive agricultural production involves more extensive use of pesticides, in particular fungicides and herbicides, resulting in a higher burden in ecosystems. Azoxystrobin ranks among the most widely-used fungicides globally. Azoxystrobin is characterized as a substance hazardous for fish as well as other aquatic life. Glyphosate is used as a nonselective herbicide and is used to treat many crops. It is also used to treat pastures, nurseries and non-agricultural land (Roundup Biactive, MSDS, Monsanto, USA). Considering the actual agricultural use of glyphosate, there is a need to monitor the substance in the aquatic environment on a regular basis (Giesy et al. 2000). Glyphosate ranks among extremely persistent pesticides with a half-life longer than 100 days (calculated from field studies). Glyphosate was found in streams following agricultural, forestry and urban applications. Cadmium is a toxicologically relevant substance contaminating the environment (Čelechovská et al. 2006; Čelechovská et al. 2008; Harkabusová et al. 2012). Zinc is an important biogenous element and an integral part of many metaloenzymes. Results from monitoring of heavy metals in living organisms were reported in the studies of Slavík et al. (2006) and Čelechovská et al. (2007). Growing environmental pollution calls for a focused interest in identifying the effects of interaction of various kinds of pollutants on living systems. For that reason, an alternative generation II biotest with Artemia franciscana is used (Dvořák and Beňová 2002).

The aim of this study was to investigate the effects of pesticides (azoxystrobin and glyphosate) heavy metals (cadmium chloride, potassium dichromate and zinc disulphate) on lethality of Artemia franciscana.

Address for correspondence:

MVDr. Marcel Falis

Department of Pharmacology and Toxicology

University of Veterinary Medicine and Pharmacy in Košice

Komenského 73, 041 81, Slovak Republic

Phone: +421915984682

E-mail: falis@uvlf.sk

http://actavet.vfu.cz/ 


\section{Materials and Methods}

In total 1,250 brine shrimp (Artemia franciscana) were used to investigate the effects of pesticides and heavy metals on their lethality. The shrimp were hatched in seawater with chemical composition according to Dvořák et al. (2005): $\mathrm{NaCl}\left(23.9 \mathrm{~g} \cdot \mathrm{l}^{-1}\right), \mathrm{MgCl}_{2} \cdot 6 \mathrm{H}_{2} \mathrm{O}\left(10.83 \mathrm{~g} \cdot \mathrm{l}^{-1}\right), \mathrm{CaCl}_{2} \cdot 6 \mathrm{H}_{2} \mathrm{O}\left(2.25 \mathrm{~g} \cdot \mathrm{l}^{-1}\right), \mathrm{KCl}\left(0.68 \mathrm{~g} \cdot \mathrm{l}^{-1}\right), \mathrm{Na}_{2} \mathrm{SO}_{4} \cdot 10 \mathrm{H}_{2} \mathrm{O}$ $\left(9.06 \mathrm{~g} \cdot 1^{-1}\right), \mathrm{NaHCO}_{3}\left(0.2 \mathrm{~g} \cdot \mathrm{l}^{-1}\right), \mathrm{SrCl}_{2}^{2} \cdot 6 \mathrm{H}_{2}^{2} \mathrm{O}\left(0.04 \mathrm{~g} \cdot \mathrm{l}^{-1}\right), \mathrm{KBr}\left(0.099 \mathrm{~g} \cdot \mathrm{l}^{-1}\right)$ and $\mathrm{H}_{3} \mathrm{BO}_{3}\left(0.027 \mathrm{~g} \cdot \mathrm{l}^{-1}\right)$ with $\mathrm{pH}=8.31$.

The following chemical solutions were prepared: pesticides [azoxystrobin (technical, purity $98.3 \%$ ) at a concentration of $0.2 \mathrm{mg} \cdot \mathrm{l}^{-1}$, glyphosate (Roundup Biactive, glyphosate $360 \mathrm{~g} \cdot \mathrm{l}^{-1}$ ) at a concentration of $500 \mathrm{mg} \cdot \mathrm{l}^{-1}$, ] and heavy metals [cadmium chloride $\left(\mathrm{CdCl}_{2} \cdot 2 \mathrm{H}_{2} \mathrm{O}\right)$ at a concentration of $25 \mathrm{mg} \cdot{ }^{-1}$, potassium dichromate $\left(\mathrm{K}_{2} \mathrm{Cr}_{2} \mathrm{O}_{7}\right)$ at a concentration of $10 \mathrm{mg} \cdot \mathrm{l}^{-1}$ and zinc sulphate $\left(\mathrm{ZnSO}_{4} \cdot 7 \mathrm{H}_{2} \mathrm{O}\right)$ at a concentration of $100 \mathrm{mg} \cdot \mathrm{l}^{-1} \mathrm{]}$. All solutions were diluted with freshly prepared seawater. In total, 125 Petri dishes used in the experiment contained $10 \mathrm{ml}$ of azoxystrobin, glyphosate, cadmium chloride, potassium dichromate and zinc sulphate separately, or their combinations; control dishes contained only sea water (Table 1).

Ten freshly hatched nauplii were placed in each polystyrene Petri dish with a diameter of $60 \mathrm{~mm}$. Petri dishes were kept at $20 \pm 1{ }^{\circ} \mathrm{C}$ in the thermostat. Each experimental set consisted of 50 nauplii which were divided into five replicates of 10 nauplii per replicate.

Live brine shrimp in each experimental set were counted after 24, 48, 72 and $96 \mathrm{~h}$. Their counts were compared with the control group, and statistically evaluated (arithmetic means \pm standard deviation) using MS Excel 2007. Dean-Dixon test (Dvořák 1995) was used to exclude outliers. The significance $(P<0.05)$ of inter-group differences was tested according to Mainland (1963).

Table 1. Design of experiment with nauplii divided into 25 groups placed in Petri dishes with azoxystrobin, glyphosate, cadmium chloride, potassium dichromate, zinc disulphate, their combinations, and with sea water (control group). The concentration of substances $\left(\mathrm{mg} \cdot \mathrm{l}^{-1}\right)$ in the groups used in the experiment are listed below.

\begin{tabular}{|c|c|c|c|c|c|}
\hline Experimental group & $\mathrm{K}_{2} \mathrm{Cr}_{2} \mathrm{O}_{7}$ & $\mathrm{CdCl}_{2} \cdot 2 \mathrm{H}_{2} \mathrm{O}$ & $\mathrm{ZnSO}_{4} \cdot 7 \mathrm{H}_{2} \mathrm{O}$ & Azoxystrobin & Glyphosate \\
\hline $\mathrm{C}$ & 0 & 0 & 0 & 0 & 0 \\
\hline A & 0 & 0 & 0 & 0.2 & 0 \\
\hline G & 0 & 0 & 0 & 0 & 500 \\
\hline $\mathrm{Cd}$ & 0 & 25 & 0 & 0 & 0 \\
\hline $\mathrm{Cr}$ & 10 & 0 & 0 & 0 & 0 \\
\hline $\mathrm{Zn}$ & 0 & 0 & 100 & 0 & 0 \\
\hline $\mathrm{AG}$ & 0 & 0 & 0 & 0.2 & 500 \\
\hline $\mathrm{GCd}$ & 0 & 25 & 0 & 0 & 500 \\
\hline $\mathrm{GCr}$ & 10 & 0 & 0 & 0 & 500 \\
\hline GZn & 0 & 0 & 100 & 0 & 500 \\
\hline $\mathrm{CdCr}$ & 10 & 25 & 0 & 0 & 0 \\
\hline CdZn & 0 & 25 & 100 & 0 & 0 \\
\hline $\mathrm{CrZn}$ & 10 & 0 & 100 & 0 & 0 \\
\hline AGCd & 0 & 25 & 0 & 0.2 & 500 \\
\hline $\mathrm{AGCr}$ & 10 & 0 & 0 & 0.2 & 500 \\
\hline AGZn & 0 & 0 & 100 & 0.2 & 500 \\
\hline $\mathrm{GCdCr}$ & 10 & 25 & 0 & 0 & 500 \\
\hline GCdZn & 0 & 25 & 100 & 0 & 500 \\
\hline GCrZn & 10 & 0 & 100 & 0 & 500 \\
\hline $\mathrm{CdCrZn}$ & 10 & 25 & 100 & 0 & 0 \\
\hline $\mathrm{AGCdCr}$ & 10 & 25 & 0 & 0.2 & 500 \\
\hline AGCdZn & 0 & 25 & 100 & 0.2 & 500 \\
\hline AGCrZn & 10 & 0 & 100 & 0.2 & 500 \\
\hline GCdCrZn & 10 & 25 & 100 & 0 & 500 \\
\hline AGCdCrZn & 10 & 25 & 100 & 0.2 & 500 \\
\hline
\end{tabular}

C - control group, A - azoxystrobin (pesticide) G - glyphosate (pesticide), Cd - cadmium chloride, $\mathrm{Cr}$ - potassium dichromate, $\mathrm{Zn}$ - zinc disulphate 


\section{Results}

Lethality of Artemia franciscana was $4 \%$ in the control group (less than $10 \%$ lethality in the control group is an essential prerequisite for test assessment). The experimental groups were compared with the control group. The group containing azoxystrobine showed a significant $(P<0.05)$ increase in lethality at all time intervals. The groups containing glyphosate and zinc separately did not show any significant $(P<0.05)$ change in lethality. Significantly increased $(P<0.05)$ lethality was observed in the group that contained cadmium after $96 \mathrm{~h}$ of exposure. The group containing chromium showed a significant $(P<0.05)$ increase in lethality after 72 and $96 \mathrm{~h}$ of exposure. Comparison of the glyphosate and azoxystrobin groups with the control group showed a significant $(P<0.05)$ increase in lethality after 48, 72 and $96 \mathrm{~h}$ of exposure. The significance of other groups compared to the control group is presented in Table 2.

Table 2. Lethality of Artemia franciscana (\%) in the control group and after different expositions to azoxystrobin, glyphosate, cadmium chloride, potassium dichromate, zinc disulphate, and their combinations.

\begin{tabular}{|c|c|c|c|c|}
\hline Experimental group & $24 \mathrm{~h}$ & $48 \mathrm{~h}$ & $72 \mathrm{~h}$ & $96 \mathrm{~h}$ \\
\hline$\overline{\mathrm{C}^{\mathrm{a}}}$ & $0 \pm 0.0$ & $0 \pm 0.0$ & $0 \pm 0.0$ & $4 \pm 4.3$ \\
\hline $\mathrm{A}^{\mathrm{b}}$ & $22 \pm 8.6^{\mathrm{a}}$ & $60 \pm 12.9^{\mathrm{a}}$ & $72 \pm 12.9^{\mathrm{a}}$ & $90 \pm 8.6^{\mathrm{a}}$ \\
\hline $\mathrm{G}$ & $0 \pm 0.0$ & $0 \pm 0.0$ & $0 \pm 0.0$ & $0 \pm 0.0$ \\
\hline $\mathrm{Cd}$ & $0 \pm 0.0$ & $0 \pm 0.0$ & $6 \pm 4.3$ & $22 \pm 12.9^{\mathrm{a}}$ \\
\hline $\mathrm{Cr}$ & $0 \pm 0.0$ & $0 \pm 0.0$ & $78 \pm 8.6^{\mathrm{a}}$ & $100 \pm 0.0^{\mathrm{a}}$ \\
\hline $\mathrm{Zn}$ & $0 \pm 0.0$ & $0 \pm 0.0$ & $4 \pm 4.3$ & $4 \pm 4.3$ \\
\hline $\mathrm{AG}$ & $8 \pm 8.6$ & $34 \pm 17.2^{\mathrm{a}, \mathrm{b}}$ & $48 \pm 12.9^{\mathrm{a}, \mathrm{b}}$ & $58 \pm 8.6^{\mathrm{a}, \mathrm{b}}$ \\
\hline GCd & $0 \pm 0.0$ & $2 \pm 4.3$ & $4 \pm 4.3$ & $6 \pm 4.3$ \\
\hline $\mathrm{GCr}$ & $0 \pm 0.0$ & $2 \pm 4.3$ & $52 \pm 8.6^{\mathrm{a}}$ & $94 \pm 4.3^{\mathrm{a}}$ \\
\hline GZn & $0 \pm 0.0$ & $8 \pm 8.6$ & $8 \pm 8.6$ & $12 \pm 12.9$ \\
\hline $\mathrm{CdCr}$ & $0 \pm 0.0$ & $2 \pm 4.3$ & $62 \pm 17.2^{\mathrm{a}}$ & $100 \pm 0.0^{\mathrm{a}}$ \\
\hline $\mathrm{CdZn}$ & $0 \pm 0.0$ & $0 \pm 0.0$ & $10 \pm 8.6$ & $34 \pm 4.3^{\mathrm{a}}$ \\
\hline $\mathrm{CrZn}$ & $0 \pm 0.0$ & $2 \pm 4.3$ & $24 \pm 8.6^{\mathrm{a}}$ & $66 \pm 4.3^{\mathrm{a}}$ \\
\hline $\mathrm{AGCd}$ & $26 \pm 8.6^{\mathrm{a}}$ & $58 \pm 8.6^{\mathrm{a}}$ & $72 \pm 4.3^{\mathrm{a}}$ & $88 \pm 8.6^{\mathrm{a}}$ \\
\hline $\mathrm{AGCr}$ & $10 \pm 8.6$ & $34 \pm 4.3^{\mathrm{a}, \mathrm{b}}$ & $88 \pm 12.9^{\mathrm{a}}$ & $98 \pm 4.3^{\mathrm{a}}$ \\
\hline AGZn & $12 \pm 8.6^{\mathrm{a}}$ & $26 \pm 17.2^{\mathrm{a}, \mathrm{b}}$ & $40 \pm 12.9^{\mathrm{a}, \mathrm{b}}$ & $56 \pm 12.9^{\mathrm{a}, \mathrm{b}}$ \\
\hline $\mathrm{GCdCr}$ & $6 \pm 4.3$ & $22 \pm 8.6^{\mathrm{a}}$ & $58 \pm 12.9^{\mathrm{a}}$ & $98 \pm 4.3^{\mathrm{a}}$ \\
\hline GCdZn & $0 \pm 0.0$ & $0 \pm 0.0$ & $2 \pm 4.3$ & $6 \pm 4.3$ \\
\hline GCrZn & $0 \pm 0.0$ & $2 \pm 4.3$ & $62 \pm 17.2^{\mathrm{a}}$ & $94 \pm 8.6^{\mathrm{a}}$ \\
\hline CdCrZn & $0 \pm 0.0$ & $8 \pm 12.9$ & $52 \pm 21.5^{\mathrm{a}}$ & $84 \pm 17.2^{\mathrm{a}}$ \\
\hline $\mathrm{AGCdCr}$ & $22 \pm 17.2^{\mathrm{a}}$ & $58 \pm 4.3^{\mathrm{a}}$ & $86 \pm 12.9^{\mathrm{a}}$ & $98 \pm 4.3^{\mathrm{a}}$ \\
\hline AGCdZn & $38 \pm 12.9^{\mathrm{a}}$ & $64 \pm 21.5^{\mathrm{a}}$ & $70 \pm 21.5^{\mathrm{a}}$ & $80 \pm 12.9^{\mathrm{a}}$ \\
\hline AGCrZn & $12 \pm 4.3^{\mathrm{a}}$ & $36 \pm 12.9^{\mathrm{a}, \mathrm{b}}$ & $74 \pm 4.3^{\mathrm{a}}$ & $94 \pm 4.3^{\mathrm{a}}$ \\
\hline GCdCrZn & $0 \pm 0.0$ & $22 \pm 17.2^{\mathrm{a}}$ & $56 \pm 8.6^{\mathrm{a}}$ & $94 \pm 8.6^{\mathrm{a}}$ \\
\hline AGCdCrZn & $10 \pm 8.6$ & $24 \pm 17.2^{\mathrm{a}, \mathrm{b}}$ & $66 \pm 30.1^{\mathrm{a}}$ & $98 \pm 4.3^{\mathrm{a}}$ \\
\hline
\end{tabular}

$\mathrm{C}$ - control group, A - azoxystrobin,(pesticide) G - glyphosate (pesticide), Cd - cadmium chloride, $\mathrm{Cr}$ - potassium dichromate, $\mathrm{Zn}$ - zinc disulphate. Data are expressed as $\mathrm{x} \pm \mathrm{SD},{ }^{\mathrm{a}, \mathrm{b}}$ differences between the values marked with the same symbol were significant $(P<0.05)$

Statistical comparisons of the azoxystrobine group with other azoxystrobine-containing groups showed that the groups containing azoxystrobine and glyphosate (AG), and azoxystrobine, glyphosate and zinc $(\mathrm{AGZn})$ had a significantly lower $(P<0.05)$ lethality 
after 48, 72 and $96 \mathrm{~h}$ of exposure. Significantly $(P<0.05)$ decreased lethality after $48 \mathrm{~h}$ of exposure was observed in groups containing azoxystrobine, glyphosate and chromium (AGCr), azoxystrobin, glyphosate, chromium and zinc (AGCrZn) and azoxystrobin, glyphosate, cadmium, chromium and zinc (AGCdCrZn). In other groups, there were no significant $(P<0.05)$ changes.

Comparison of the azoxystrobin and glyphosate (AG) group with the other groups containing that combination showed that the cadmium group (AGCd) displayed a significant $(P<0.05)$ increase in lethality at all time intervals. The groups containing chromium (AGCr), cadmium and chromium (AGCdCr), and chromium with zinc (AGCrZn) showed a significant increase in lethality after 72 and $96 \mathrm{~h}$ of exposure. The cadmium and zinc group $(\mathrm{AGCdZn})$ showed a significant $(P<0.05)$ increase in lethality after 24,72 and $96 \mathrm{~h}$ of exposure.

\section{Discussion}

In this study, we examined the effect of exposure of brine shrimp to pesticides (azoxystrobin and glyphosate) and heavy metals (cadmium chloride, potassium dichromate, zinc disulphate) and their combinations.

Azoxystrobin is highly toxic for freshwater invertebrates such as the water flea; its $\mathrm{EC}_{50}$ is $259 \mathrm{ppb}$ (Pesticide fact sheet: Azoxystrobin). This was proven also in our study, since brine shrimp exposed to azoxystrobin showed relatively high lethality at all the time intervals tested. Previous studies ranked azoxystrobin among pesticides with moderate persistence in terrestrial environment with general degradation half-life within the range of 72 to 164 days (Pesticide fact sheet: Azoxystrobin). The fate and behaviour of azoxystrobin in salt water is the same as in fresh water; sensitivity of marine organisms to azoxystrobin effects is similar to that of freshwater organisms (Azoxystrobin, Enviro facts Syngenta Crop Protection). In case of glyphosate, we did not observe any lethality in brine shrimp during the testing period. Cox (2000) observed that fish and aquatic invertebrates were more sensitive to glyphosate effects than terrestrial organisms.

Concentrations of cadmium in the soil in some agricultural areas of Slovakia are in the range from 7.04 to $10.78 \mathrm{mg} \cdot \mathrm{kg}^{-1}$ (Hecl 2010). In our study, we used a higher concentration $\left(25 \mathrm{mg} \cdot \mathrm{kg}^{-1}\right)$ and all groups of shrimp exposed to chromium showed high lethality, regardless of other substances it was combined with. This can be explained by the properties of chromium compounds which cause protein coagulation and have corrosive effects. Nováková et al. (2007) observed that cadmium in combination with $\mathrm{ZnSO}_{4}$ caused a significant decrease in lethality to Artemia franciscana; however, this effect was not shown in our study. Concentration of zinc in the soil in agricultural areas of eastern Slovakia is in the range from 48.28 to $584 \mathrm{mg} \cdot \mathrm{kg}^{-1}$ (Hecl 2004). In our study we used a concentration of $100 \mathrm{mg} \cdot \mathrm{l}^{-1}$; lethality to Artemia franciscana was comparable to the control group. We found that lethality of shrimp increased gradually in time when they were exposed to a combination of four or five chemicals. The results of this study showed that the actual toxicity of chemicals in the environment is different, taking into account the toxicity combined with other contaminants. However, interactions of all these chemicals are not taken into consideration during standard risk assessment of the use of plant protection products.

We found that shrimp exposed to azoxystrobin showed better survival rates in Petri dish containing azoxystrobin and glyphosate in combination with zinc. The explanation of that phenomenon may be the protective effects of chromium and zinc and their compounds from the harmful effects of azoxystrobin. Shrimp exposed to glyphosate and zinc in combination showed an increase in lethality compared to the shrimp exposed only to glyphosate and zinc separately. The results of the study indicate different toxicity of pesticides in the presence 
of other pesticides or heavy metals. Based on these results, the use of plant protection products in polluted environment should be well considered. Further investigation of the combined toxicity of pollutants, mainly heavy metals and pesticides used during the growing season is needed.

\section{Acknowledgements}

The study was supported by grant project VEGA (No. 1/0393/08) and the National Reference Laboratory for Pesticides (NRL UVLF-KE).

\section{References}

Azoxystrobin. Enviro facts Syngenta Crop Protection. Available at: http://www.syngentacropprotection.com/ env stewardship/futuretopics/Azoxy2005.pdf. Last modified June 21, 2005. Accessed June 25, 2013

Cox C. Glyphosate factsheet. J Pestic Reform 108: 3. Available at: http://www.mindfully.org/Pesticide/RoundupGlyphosate-Factsheet-Cox.htm. Last modified October, 2000. Accessed June 26, 2013

Čelechovská O, Literák I, Ondruš S, Pospíšil Z 2006: Heavy metals in Brown bears from the Central European Carpathians. Acta Vet Brno 75: 501-506

Čelechovská O, Malota L, Zima S 2008: Entry of heavy metals into food chains: a 20-year comparison study in Northern Moravia (Czech Republic) Acta Vet Brno 77: 645-652

Čelechovská O, Svobodová Z, Žlábek V, Macharáčková B 2007: Distribution of metals in tissues of the Common carp (Cyprinus carpio L.). Acta Vet Brno 76: 93-100

Dvořák P 1995: A modified test with $A$. salina for examination of effects of foreign substance interaction. In: Proceedings of toxicity and biodegradability of waste and substances relevant in aquatic environment (In Czech). Výzkumný ústav rybářský a hydrobiologický a Aqachemie, Milenovice 25-29

Dvořák P, Beňová K 2002: Investigating interaction of low doses of ionizing radiation and risk factors using Artemia salina biotest. Folia Vet 46: 195-197

Dvořák P, Šcman E, Beňová K 2005: The development of a ten day biotest using Artemia salina nauplii. Biologia, Bratislava 60: 593-597

Giesy JP, Solomon KR, Dobson S 2000: Ecotoxicological risk assessment for roundup herbicide. Rev Environ Contam T 167: 35-120

Harkabusová V, Čelechovská O, Lavičková A, Svobodová Z 2012: Monitoring of risk metals in chub (Leuciscus cephalus L.) from the Svitava and Svratka rivers in the urban area of Brno, Czech Republic. Acta Vet Brno 81: $69-73$

Hecl J 2004: The zinc content at carrote root on soils with increased content risk substances cultivated. Available at: http://www.agroporadenstvo.sk/rv/zelenina/zinok.htm. Last modified September 23, 2004. Accessed December 11, 2013.

Hecl J 2010: Effect of selected amendments on cadmium content in the soil and its transfer into crops. Agriculture 56: $52-58$

Mainland D 1963: Elementary medical statistics, Saunders 2nd ed, New York, 381p.

Nováková J, Daňová D, Strišková K, Hromada R, Mičková H, Rabišková M 2007: Zinc and cadmium toxicity using a biotest with Artemia franciscana. Acta Vet Brno 76: 635-642

Pesticide fact sheet. Azoxystrobin. Available at: http://www.pmac.net/azoxy.htm. Last modified June 25, 2013. Accessed June 25, 2013

Roundup Biactive, MSDS, Monsanto Available at: http://www.sdslibrary.monsanto.com/MSDS\%20Datasheet/9 2EBB78C4056D48686256CFC00248BC2/Roundup\%20Biaktiv-5061cs-cz.pdf. Last modified June 26, 2013. Accessed June 26, 2013

Slavík P, Illek J, Zelený T 2006: Zinc and copper status of beef cattle in the Šumava region, Czech Republic. Acta Vet Brno 75: 485-488 